\title{
Morphological and genomic characterization of Rhynchospora tenuis complex (Cyperaceae) and its taxonomic implications
}

\author{
Caracterização morfológica e genômica do complexo Rhynchospora tenuis (Cyperaceae) \\ e suas implicações taxômicas
}

\author{
Vanessa Silva Michelan ${ }^{1}$, Rafael Trevisan ${ }^{2}$, Carlos Roberto Maximiano da Silva ${ }^{1}$, \\ Rogério Fernandes de Souza ${ }^{1}$, Modesto Luceño ${ }^{3} \&$ André Luís Laforga Vanzela ${ }^{1,4}$
}

\begin{abstract}
Species of Rhynchospora sect. Tenues are morphologically very similar. Rhynchospora tenuis complex is the most problematic species complex in this group and it concentrates entities of difficult delimitation, as is the case of $R$. tenuis, $R$. tenuis subsp. austro-brasiliensis and $R$. enmanuelis. Samples of these three taxonomic entities, besides $R$. junciformis and $R$. breviuscula (Dichromena), were analyzed in a comparative way using morphologic, cytogenetic and molecular tools. Despite of high morphological similarity between these taxa, $R$. tenuis was separated from $R$. tenuis subsp. austro-brasiliensis and $R$. enmanuelis according to chromosome numbers $(2 n=4$ and $2 n=18)$ and ISSR markers. The combined analysis of shape and size of achenes and stylopodium, number of spikelets, cytogenetic features and molecular markers suggest a clear proximity among Rhynchospora junciformis, $R$. tenuis subsp. austro-brasiliensis and $R$. enmanuelis, in relation to $R$. tenuis. These data indicate the need for a new taxonomic review of $R$. sect. Tenues, mainly to solve the status and nomenclatural situation of $R$. tenuis subsp. austro-brasiliensis and $R$. enmanuelis.
\end{abstract}

Key words: cytotaxonomy, dysploidy, ISSR, holocentric chromosomes, Poales.

\begin{abstract}
Resumo
As espécies de Rhynchospora sect. Tenues são morfologicamente muito similares. O complexo Rhynchospora tenuis é o mais problemático e concentra entidades de difícil delimitação, como é o caso de $R$. tenuis, R. tenuis subsp. austro-brasiliensis e R. enmanuelis. Amostras dessas três entidades taxonômicas, além de R. junciformis e R. breviuscula (Dichromena), foram analisadas de modo comparativo usando análises morfológicas, citogenéticas e moleculares. Apesar da elevada similaridade morfológica entre esses taxa, $R$. tenuis foi separada de $R$. tenuis subsp. austro-brasiliensis e $R$. enmanuelis de acordo com os números cromossômicos $(2 n=4 \mathrm{e}$ $2 n=18$ ) e marcadores ISSR. A análise combinada da forma e tamanho dos aquênios e estilopódio, número de espiguetas, características citogenéticas e de marcadores moleculares, sugere uma clara proximidade entre Rhynchospora junciformis, R. tenuis subsp. austro-brasiliensis e R. enmanuelis, em relação à R. tenuis. Além disso, esses dados indicam a necessidade de uma nova revisão taxonômica para $R$. sect. Tenues, principalmente para resolver o status e a situação nomenclatural de $R$. tenuis subsp. austro-brasiliensis e R. enmanuelis.

Palavras-chave: citotaxonomia, disploidia, ISSR, cromossomos holocêntricos, Poales.
\end{abstract}

\section{Introduction}

Rhynchospora sect. Tenues Kükenthal (Cyperaceae) is characterized by the presence of small plants with channeled to filiform leaves and achenes with transverse wrinkles and stylopodium not included in a depression of the apex of the achene (Rocha \& Luceño 2002). This section includes ca. 20 species, fourteen of these occurring in Brazil (Alves et al. 2009). Seventeen species were described by Kükenthal (1951), besides another three were described by Rocha \& Luceño (2002). The number of taxa in this section is however doubtful due to the Rhynchospora tenuis complex, which may involve Rhynchospora tenuis

\footnotetext{
${ }^{1}$ Universidade Estadual de Londrina, Depto. Biologia Geral, CCB, C.P. 6001, 86051-990, Londrina, PR, Brazil.

${ }^{2}$ Universidade Federal de Santa Catarina, Depto. Botânica, 88040-970, Florianópolis, SC, Brazil.

${ }^{3}$ Universidad Pablo de Olavide, Depto. Biología Molecular y Ingeniería Bioquímica, Ctra. de Utrera, km. 1, 41013, Sevilla, Spain.

${ }^{4}$ Author for correspondence: andrevanzela@uel.br
} 
Willd. ex Link, R. tenuis subsp. austro-brasiliensis T. Koyama, $R$. enmanuelis Luceño and Rocha, $R$. riparia (Nees) Boeck., and $R$. emaciata (Nees) Boeck. (Kükenthal 1951; Koyama 1972; Rocha \& Luceño 2002). Rhynchospora riparia and $R$. emaciata possess striking features that distinguish them from $R$. tenuis (Vanzela et al. 2000; Rocha \& Luceño 2002; Strong 2006). Although $R$. riparia was considered the variety $R$. tenuis var. congesta Kükenthal by Kükenthal (1951), and as the subspecies $R$. tenuis subsp. riparia (Nees) Boeck. by Koyama (1972), it is easily differentiated from $R$. tenuis due to canaliculated, larger and more rigid leaves, congested inflorescences, frequent occurrence of decumbent stalks and chromosome number $2 n=10$ (see Vanzela et al. 2000). Rhynchospora emaciata has also been considered as a synonym of $R$. tenuis (Koyama 1972, Thomas 1994), despite of evident distinct morphological features as the presence of solitary spikelets, 6-7 mm long, trigonal stalks without lateral branches, pale color achenes with an entirely marginate style base and $2 n=10$ (see Vanzela et al. 2000). Nevertheless, the major taxonomic confusion involves $R$. tenuis, $R$. tenuis subsp. austro-brasiliensis and $R$. enmanuelis, which are more similar morphologically.

Species of Rhynchospora, as well as other representatives of the Cyperaceae, have holocentric chromosomes (Vanzela et al. 1996; Vanzela \& Colaço 2002), which favor the occurrence and maintenance of numeric chromosome changes, as observed in Carex sociata Boott (Ohkawa et al. 2000) and Eleocharis maculosa (Vahl) Roem. and Schult. (Da Silva et al. 2008a). Despite karyotype variations associated with symploidy and/or agmatoploidy were reported for some species as $R$. tenuis and R. globosa Vahl (Arguelho et al. 2012), polyploidy has been considered the most important event in karyotype differentiation in this genus, occurring in 59\% of Rhynchospora species studied (Vanzela et al. 2000). Nevertheless, Rhynchospora tenuis shows the smallest chromosome number $(2 n=4)$ among the Cyperaceae and plants, in general (Vanzela et al. 1996). The chromosome numbers were described to seven other species of the Rhynchospora sect. Tenues: $R$. emaciata, $R$. riparia, and $R$. nanuzae Luceño and Rocha with $2 n=10$, and $R$. contracta (Nees) J. Raynal and $R$. enmanuelis, $R$. austro-brasiliensis and $R$. junciformis with $2 n=18$ (Vanzela et al. 2000; Arguelho et al. 2012).
The literature points out problems in $R$. sect. Tenues species circumscription with some taxonomic conflicts, mainly on species close to $R$. tenuis, which presents also considerable karyotype variability. In this study we have chosen samples from three taxonomic conflicting taxa: $R$. tenuis, $R$. tenuis subsp. austro-brasiliensis and $R$. enmanuelis, which are very common in the southeast and southern Brazil. Besides two other species (Rhynchospora junciformis (Kunth) Böckeler of $R$. sect. Tenues and Rhynchospora breviuscula H. Pfeiff of Rhynchospora sect. Dichromena (Michaux) Grisebach) have been chosen for comparison using morphologic, cytogenetic and molecular analyses. The discussion considers the value of these different diagnostic characters in order to help future taxonomic revisions.

\section{Material and Methods}

Five individuals of each taxa, Rhynchospora tenuis (three populations), $R$. tenuis subsp. austro-brasiliensis (five populations), $R$. enmanuelis (two populations), $R$. junciformis (one population) and $R$. breviuscula (one population) were collected in three Brazilian states: Paraná, São Paulo, and Mato Grosso do Sul (Tab. 1). The samples of $R$. enmanuelis were obtained from Tupã, in the same locality where the type specimen was collected (Rocha \& Luceño 2002), and in São Paulo, in the same locality in which Vanzela et al. (2000) reported chromosome number. All samples were maintained in a greenhouse at the Laboratório de Biodiversidade e Restauração de Ecossistemas (LABRE) in the Universidade Estadual de Londrina, Londrina, Paraná, Brazil.

\section{Morphological analysis}

Morphologic analysis was performed in five individuals of each species collected. In this evaluation were considered: i) size of plants, leaves and inflorescences, ii) size and shape of spikelets, achenes and stylopodium, iii) number of spikelets, anthers and axillary corymbs and iv) color of achenes. The measurements were made using graph paper, ruler, magnifying glass and stereomicroscope. The vouchers are kept in the FLOR herbarium. 


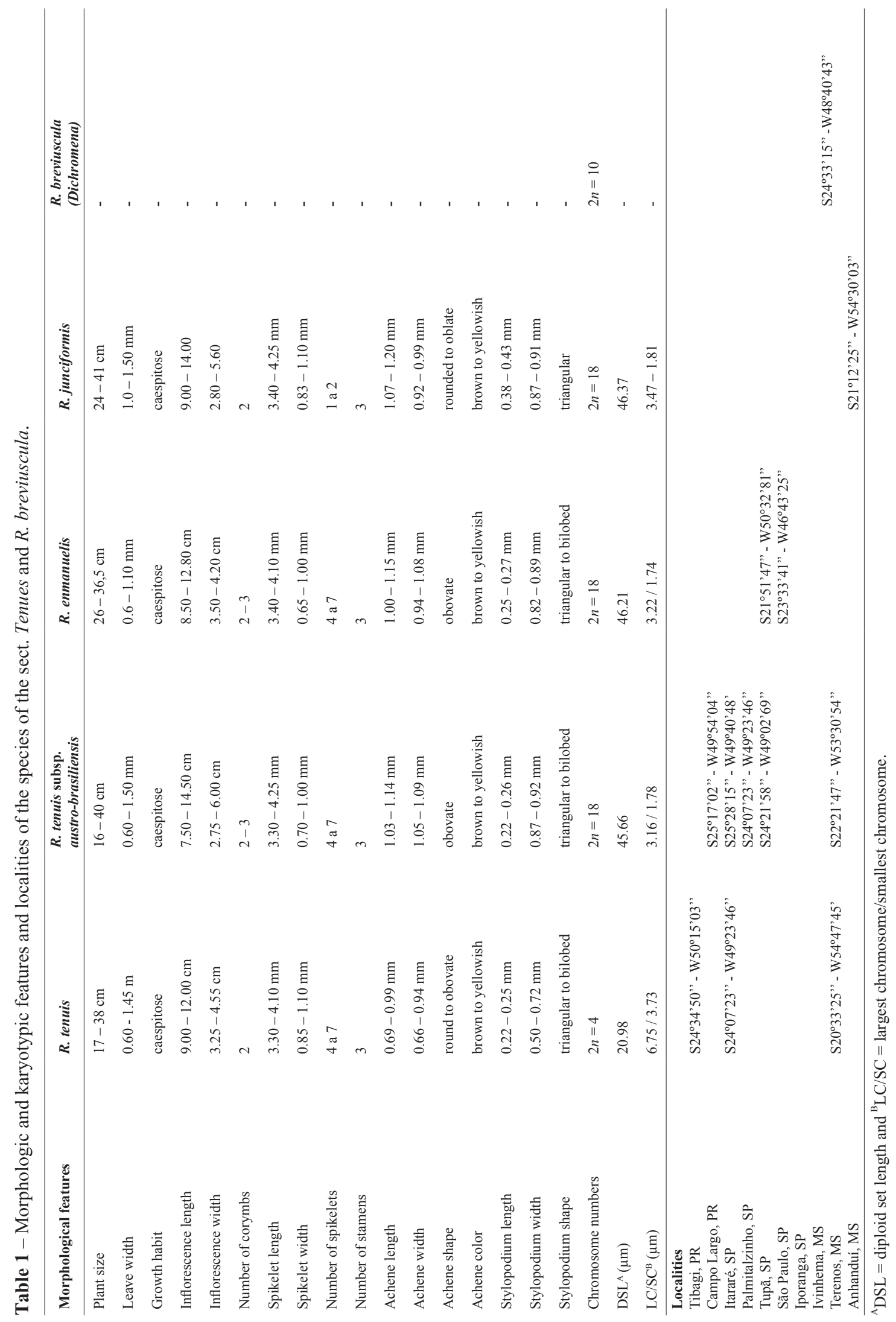


Cytogenetic analysis

Rhyncospora tenuis, $R$. tenuis subsp. austrobrasiliensis, $R$. enmanuelis and $R$. junciformis were submitted to cytogenetic analyses. Somatic chromosomes were obtained from root tips, which were pretreated with $2 \mathrm{mM} 8$-hydroxyquinoline for $24 \mathrm{~h}$ at $10^{\circ} \mathrm{C}$, fixed in absolute ethanol:glacial acetic acid $(3: 1, \mathrm{v}: \mathrm{v})$ for $12 \mathrm{~h}$ and kept at $-20^{\circ} \mathrm{C}$ until used, as described by Vanzela et al. (2000). Root tips were digested for $4 \mathrm{~h}$ in a mixture of $2 \%(\mathrm{v} / \mathrm{v})$ cellulase and $20 \%(\mathrm{v} / \mathrm{v})$ pectinase, further hydrolyzed in 1 $\mathrm{N} \mathrm{HCl}$ at $60^{\circ} \mathrm{C}$ for $11 \mathrm{~min}$, dissected in a drop of $60 \%$ acetic acid and squashed. The cover slips were removed after freezing in liquid nitrogen. The material was stained with $2 \%$ Giemsa and permanent slides mounted in Entellan. The size of the chromosomes and the length of the diploid set were determined based on five different metaphases of each species/population.

For meiotic chromosome analysis, anthers were collected and immediately fixed in absolute ethanol:glacial acetic acid (3:1, v:v) for $12 \mathrm{~h}$, and then kept at $-20^{\circ} \mathrm{C}$ until used, as described by Vanzela et al. (2000). Samples were hydrolyzed in $1 \mathrm{~N} \mathrm{HCl}$ at $60^{\circ} \mathrm{C}$ for $8 \mathrm{~min}$ and squashed in a drop of $45 \%$ acetic acid. The coverslips were removed after freezing, as described above, and the samples were stained with 2\% Giemsa. Slides were mounted with Entellan.

Fluorescent in situ hybridization (FISH) was performed according to Da Silva et al. (2008b). Slides were prepared with root tips pretreated as described above, without acid hydrolysis. The 45S rDNA probe from Triticum aestivum L. (pTa71; Gerlach \& Bedbrook 1979) was labeled with biotin-14-dATP by nick translation and $100 \mathrm{ng}$ of probe $(4 \mu \mathrm{L})$ were mixed in a solution containing $100 \%$ formamide $(15 \mu \mathrm{L}), 50 \%$ polyethylene glycol $(6 \mu \mathrm{L}), 20 \times \operatorname{SSC}(3 \mu \mathrm{L}), 100 \mathrm{ng}$ of calf thymus DNA $(1 \mu \mathrm{L})$, and $10 \% \operatorname{SDS}(1 \mu \mathrm{L})$. The samples were denatured at $90^{\circ} \mathrm{C}$ for $10 \mathrm{~min}$ and hybridization was performed at $37^{\circ} \mathrm{C}$ overnight in a humidified chamber. Post-hybridization washes were carried out in $2 \times \mathrm{SSC}$ with $70 \%$ stringency. The probe was detected with avidin-FITC conjugate at $37^{\circ} \mathrm{C}$ for $1 \mathrm{~h}$ and the post-detection washes were performed in $4 \times \mathrm{SSC} / 0.2 \%$ Tween 20 , all at room temperature. Slides were mounted with $25 \mu \mathrm{L}$ of DABCO solution, composed of glycerol (90\%), 1,4-diaza-bicyclo(2,2,2)-octane (2.3\%), $20 \mathrm{mM}$ Tris-HCl, $\mathrm{pH} 8.0$ (2\%), $2.5 \mathrm{mM}$ $\mathrm{MgCl} 2(4 \%)$ and distilled water (1.7\%), with $4 \mu \mathrm{L}$ of $2 \mu \mathrm{g} / \mathrm{mL}$ DAPI.
All the chromosome images were acquired in grayscale with a Leica DM4500 B microscope coupled with a DFC 300FX camera. The FISH images were overlapped with red color for DAPI and greenish-yellow (45S rDNA) for FITC, using the Leica IM50 4.0 software. The images were optimized for best contrast and brightness with Adobe Photoshop CS3 version 10.0 software.

Genomic DNA extraction and ISSR-PCR

Genomic DNA of each species, including the $R$. breviuscula as outgroup, was isolated from young leaves using a CTAB extraction buffer $(2 \%$ cetyltrimethyl ammonium bromide, $1.4 \mathrm{M} \mathrm{NaCl}$, $20 \mathrm{mM}$ EDTA, $100 \mathrm{mM}$ Tris-HCl, $\mathrm{pH}$ 8.0, 1\% polyvinylpyrrolidone, and $0.2 \% \beta$-mercaptoethanol) at $60^{\circ} \mathrm{C}$ for $1 \mathrm{~h}$, and subsequently treated with $0.01 \%$ proteinase $\mathrm{K}$ at $60^{\circ} \mathrm{C}$ for $30 \mathrm{~min}$, as described by Doyle and Doyle (1990), with modifications. Samples were purified with phenol/chloroform (1:1; $\mathrm{v} / \mathrm{v})$ and chloroform/isoamyl alcohol $(24: 1 ; \mathrm{v} / \mathrm{v})$ and treated with $100 \mu \mathrm{g} / \mathrm{mL}$ RNase. DNA concentration was estimated using a DyNA Quant 200 (Hoefer, Inc., USA).

For ISSR-PCR (inter simple sequence repeat - polymerase chain reaction) (Zietkiewicz et al. 1994), the following oligomers were used as primers: $\mathrm{TGG}_{5}, \mathrm{GA}_{9}+\mathrm{C}, \mathrm{AAG}_{5}, \mathrm{GTG}_{6}, \mathrm{GACA}_{4}, \mathrm{CAG}_{5}, \mathrm{GAG}_{5}$ and TGA . PCR was performed in a final volume of $25 \mu \mathrm{L}$, containing $2.5 \mu \mathrm{L}$ of $10 \times$ enzyme buffer, $2.0 \mu \mathrm{L}$ of $50 \mathrm{mM} \mathrm{MgCl}, 2.0 \mu \mathrm{L}$ of $10 \mathrm{mM}$ dNTP, $1.0 \mu \mathrm{L}$ of $5 \mu \mathrm{M}$ primer (each), $0.2 \mu \mathrm{L}$ of Taq DNA polymerase $(1 \mathrm{U}), 2.0 \mu \mathrm{L}$ of template DNA $(10 \mathrm{ng} /$ $\mu \mathrm{L}$ ) and $15.3 \mu \mathrm{L}$ of ultrapure $\mathrm{H}_{2} \mathrm{O}$. Samples were amplified using a PTC $100 \mathrm{MJ}$ Research thermal cycler, programmed for $3 \mathrm{~min}$ at $94^{\circ} \mathrm{C}$, followed by 36 cycles of $1 \mathrm{~min}$ at $94^{\circ} \mathrm{C}, 30 \mathrm{sec}$ at $45^{\circ} \mathrm{C}$ and $1 \mathrm{~min}$ at $72^{\circ} \mathrm{C}$, with a final extension at $72^{\circ} \mathrm{C}$ for $5 \mathrm{~min}$. To test the consistency and reproducibility of reactions, products from three different PCR reactions were submitted to electrophoresis in $1.4 \%$ Ultrapure agarose (Invitrogen ${ }^{\mathrm{TM}}$, USA) at $3 \mathrm{~V} / \mathrm{cm}$ and stained with $3 \mu \mathrm{L}$ of $10 \mathrm{~g} / \mathrm{mL}$ ethidium bromide and compared. Only consistent results were used for the analysis. For analysis of ISSR polymorphisms, $5 \mu \mathrm{L}$ of each PCR product of each sample were submitted to $9 \%$ polyacrylamide gel electrophoresis (Invitrogen ${ }^{\mathrm{TM}}$, USA) at $8 \mathrm{~V} / \mathrm{cm}$, and the bands revealed with $10 \%$ silver nitrate.

The ISSR bands were analyzed as binary characters ( 0 and 1$)$ with the TREECON software Version $1.3 \mathrm{~b}$. Genetic similarity data matrices were 
constructed using the method of Nei and Li (1979) and group average clustering were performed by UPGMA (unweighted pair group method with arithmetic mean) with 1000 bootstrap replicates. We have included $R$. breviuscula to this comparison because it belongs to $R$. sect. Dichromena, which was considered by Thomas et al. (2009) as a very close group of $R$. sect. Tenues. The phenogram has been constructed using data of more distant populations of $R$. tenuis and $R$. tenuis subsp. austro-brasiliensis in order to obtain a tree with the better resolution.

\section{Results}

The average values of the morphometric measurements of at least five fertile individuals of each taxonomic entity and population are shown in Table 1. The results showed overlap of values in most morphologic traits among all taxonomic entities. The achenes of $R$. tenuis varied significantly in size, reaching $50 \%$ size variation among populations (Fig. 1a-c). In addition, $R$. tenuis exhibited spherical/ obovate achenes, while $R$. tenuis subsp. austrobrasiliensis and $R$. enmanuelis showed obovate ones (Fig. 1d-e, respectively). Rhynchospora junciformis showed spherical/oblate achenes, with size very similar to that of $R$. tenuis subsp. austrobrasiliensis and R. enmanuelis (Fig. $1 \mathrm{f}$ and Table 1). In general, the stylopodia were relatively similar in shape (triangular bilobed) in all taxonomic entities, except for Rhynchospora junciformis, which showed a triangular shape.

In general, the inflorescences exhibited two axillary corymbs, however, up to three were found in R. tenuis subsp. austro-brasiliensis and $R$. enmanuelis. The distance between corymbs varied in all species (Table 1). Rhynchospora tenuis, $R$. tenuis subsp. austro-brasiliensis and $R$. enmanuelis showed four to seven spikelets grouped, but $R$. junciformis showed one to two spikelets in the tip of culms. The spikelets of all species appeared curved when mature, but this feature was less pronounced in $R$. tenuis. All species exhibited three stamens, with some variations in size in different flowers (Fig. $1 \mathrm{~g}-\mathrm{i})$. However, $R$. tenuis subsp. austro-brasiliensis and $R$. enmanuelis showed staminodes of different sizes in different flowers (Fig. 1i).

Cytogenetic analysis showed $2 n=4$ for $R$. tenuis (Fig. 2a) and $2 n=18$ for $R$. tenuis subsp. austro-brasiliensis, $R$. junciformis and $R$. enmanuelis (Fig. 2b-d, respectively), without visible karyotype variations among different populations of each species. Rhynchospora tenuis showed a karyotype composed of two large and two small chromosomes and a diploid set size of about $21 \mu \mathrm{m}$. Rhynchospora tenuis subsp. austro-brasiliensis, R. enmanuelis, and $R$. junciformis displayed very similar karyotypes, with chromosomes decreasing slightly in size. The diploid set size in these three species was more than twice that found in $R$. tenuis (Tab. 1). In meiosis, just the chromosomes of $R$. enmanuelis and $R$. tenuis subsp. austro-brasiliensis were analyzed, pairing as $7^{\mathrm{II}}+1^{\mathrm{IV}}$ (Fig. 2e-f) and only a very few cells were observed with nine bivalents. It is important to mention that some technical limitations hindered the analysis about meiosis. Due to extremely small size of anthers (a little over a millimeter) and the occurrence of some unviable anthers, with formation of staminodes, we did not get sporocytes with good quality enough to conduct a safe analysis of frequency to test the irregular meiotic configurations. In addition, because the holocentric chromosomes make possible karyotype changes resulting from symploidy and agmatoploidy and the occurrence of chromosome reduction in $R$. tenuis $(2 n=4)$ and tetravalents in $R$. tenuis subsp. austro-brasiliensis and $R$. enmanuelis, we chose not to organize the chromosomes of these species in pairs to not incur pairing errors. The FISH with $45 \mathrm{~S}$ rDNA probe revealed terminals signals in the two small chromosomes for $R$. tenuis (Fig. $2 \mathrm{~g}$ ). Rhynchospora tenuis subsp. austro-brasiliensis, $R$. enmanuelis (data not showed) and $R$. junciformis, showed six chromosomes with terminal hybridization signals (Figs. 2h-i), but $R$. junciformis exhibits signals in large and medium chromosomes while in the other two species the signals were in the large, medium and small chromosomes.

The eight primers used in ISSR-PCR produced fragments of 350 to $1800 \mathrm{bp}$. After the repeatability test, 116 polymorphic loci were considered and used in the genome comparison. Rhynchospora tenuis shared few bands with $R$. tenuis subsp. austrobrasiliensis, but the latter shared several bands with $R$. enmanuelis and $R$. junciformis (see an example in the Fig. 3). UPGMA grouping using the Nei \& Li (1979) similarity index clearly separated $R$. breviuscula from the other species, with only $9 \%$ similarity (Fig. 4). The taxa of the $R$. sect. Tenues comprised two groups, with 39\% similarity. Group A consisted of two populations of $R$. tenuis, with $77 \%$ of similarity. Group B, which comprised R. tenuis subsp. austro-brasiliensis, R. enmanuelis and $R$. junciformis, was divided into three subgroups, both with $60 \%$ similarity. The first subgroup, named B1, includes only one population of $R$. junciformis, and the second or $\mathrm{B} 2$, grouped $R$. tenuis subsp. austro-brasiliensis 

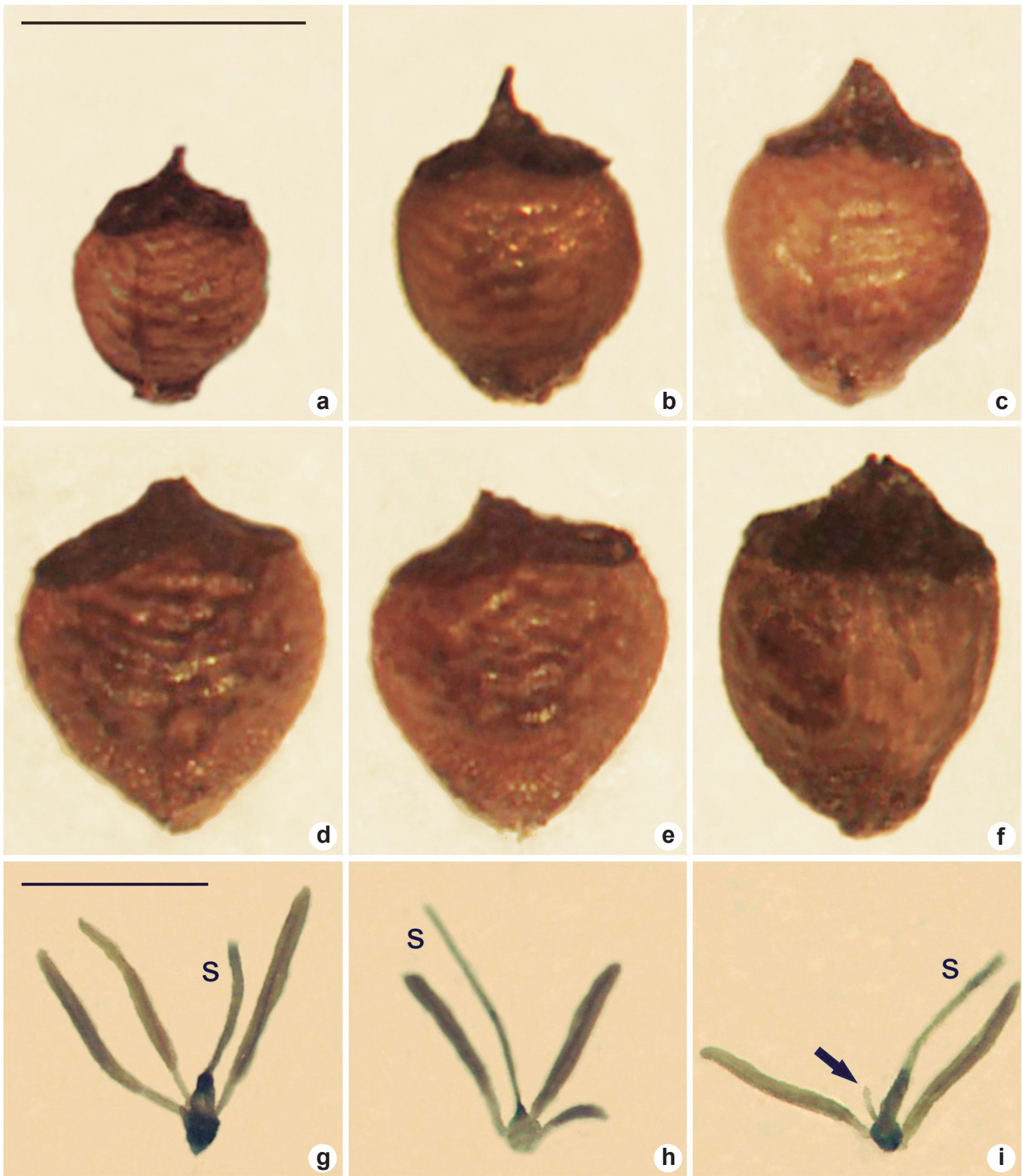

Figure 1 - Fruit and flower morphology of Brazilian species of Rhynchospora section Tenues - a-f. image of the achenes; a-c. achenes of Rhynchospora tenuis. Note the evident variation in the size of achenes from different samples. d. achene of $R$. tenuis subsp. austro-brasiliensis; e. achene of $R$. enmanuelis. Note the similarity between achenes of $\mathrm{d}$ and $\mathrm{e}-\mathrm{f}$. achene of $R$. junciformis. Note the wider stylopodium in relation to other species. $\mathrm{g}$-i. anthers of $R$. enmanuelis. Note the existence of three anthers of similar size $(\mathrm{g})$, two larger and one smaller (h) and little staminodes indicated by arrow (i). $\mathrm{S}=$ style. Scale bars $=1 \mathrm{~mm}$. 


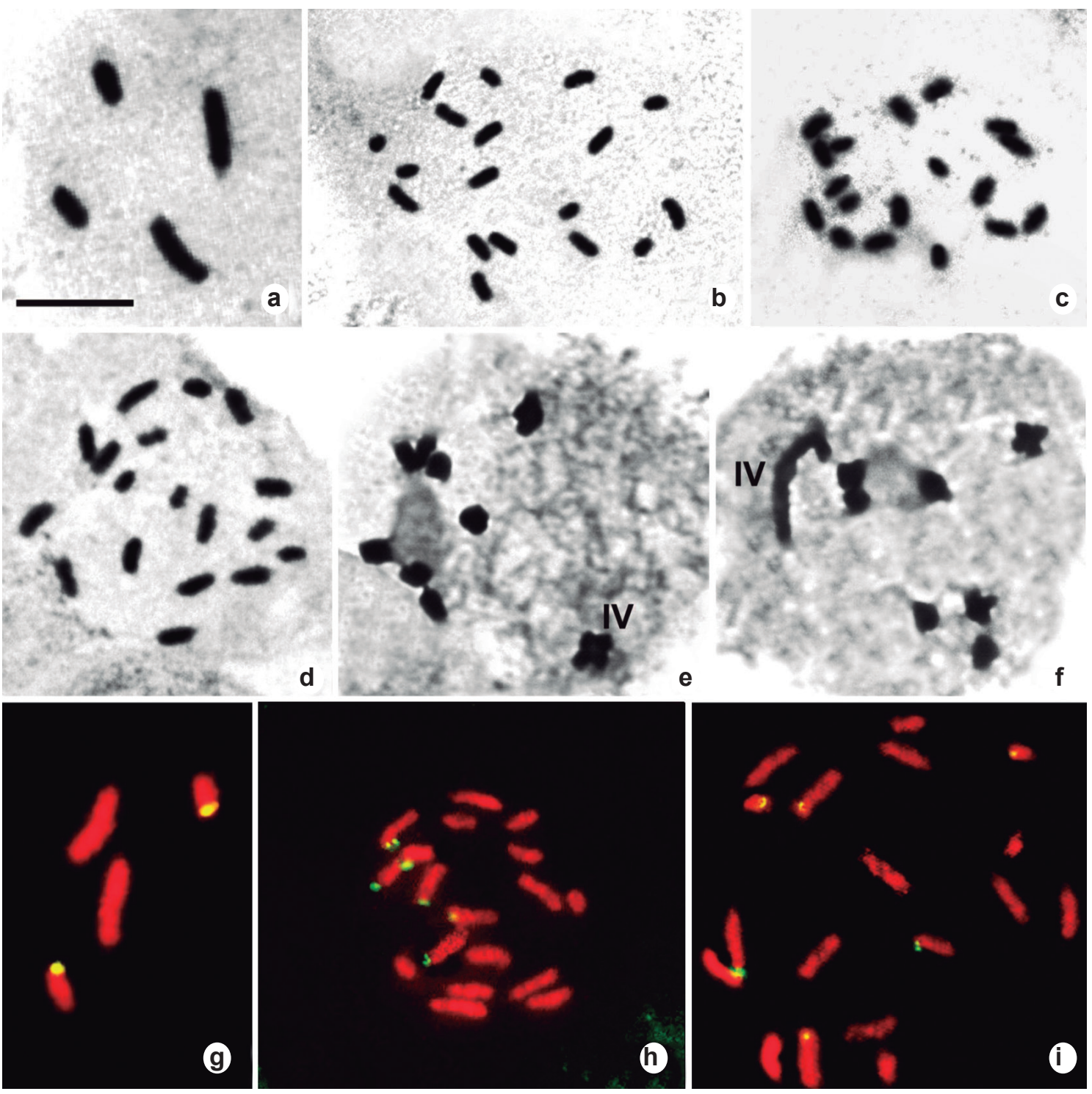

Figure 2 - Chromosomes of Brazilian species of Rhynchospora section Tenues - a. mitotic chromosomes of Rhynchospora tenuis with $2 n=4$; b. R. tenuis subsp. austro-brasiliensis with $2 n=18$; c. R. junciformis with $2 n=18$; d. $R$. enmanuelis with $2 n=18$. e-f. meiotic chromosomes of $R$. tenuis subsp. austro-brasiliensis and $R$. enmanuelis with $7^{\mathrm{II}}$ and $1^{\mathrm{IV}}$. Numbers indicate tetravalent configurations; g. FISH with $45 \mathrm{~S}$ rDNA probe in mitotic chromosomes of $R$. tenuis; h. R. junciformis; i. R. tenuis subsp. austro-brasiliensis. Bar $=10 \mu \mathrm{m}$.

and $R$. enmanuelis with at least $68 \%$ similarity. In group $\mathrm{C}$, one population of $R$. tenuis subsp. austrobrasiliensis (Itararé, SP) showed $85 \%$ similarity with $R$. enmanuelis from São Paulo, SP (Fig. 4).

\section{Discussion}

Rhynchospora tenuis, $R$. tenuis subsp. austrobrasiliensis and $R$. enmanuelis are easily confused in the field, mainly because the features used in diagnosis overlap in size and shape. Our analysis also showed overlapping of the values for all morphologic characters, including $R$. junciformis, except for shape of stylopodium in the last one. When our data on morphology were compared with the morphological features reported by Barros (1960), Koyama (1972), Rocha \& Luceño (2002) and Strong (2006) all these species were found to share similar features. However, when our results on size and shape of achenes and stylopodium, number of terminal spikelets, karyotypic features and ISSR 


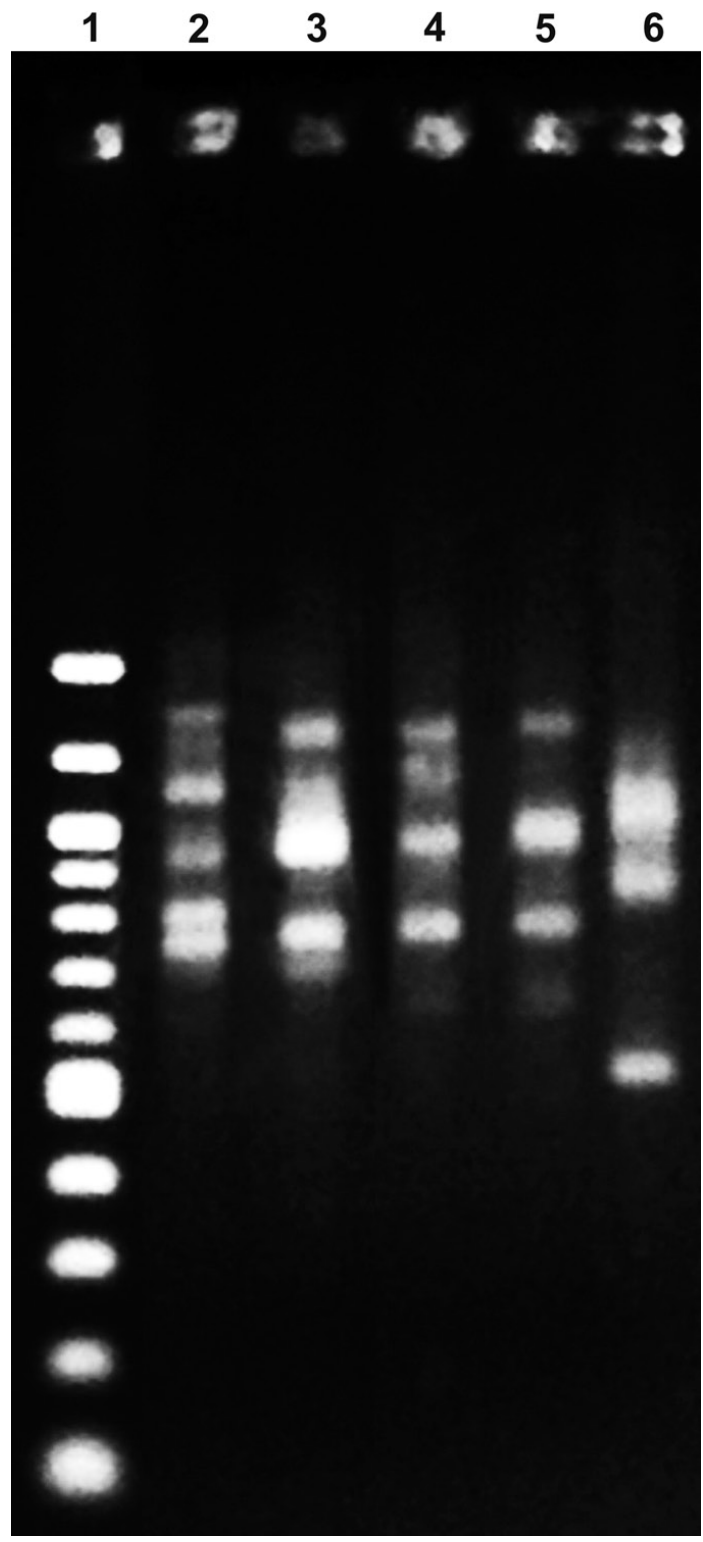

Figure 3 - Agarose gel demonstrating the repeatability tests, which shows the bands obtained after ISSR-PCR with the GA +C primer. 1) $100 \mathrm{bp}, 2) R$. tenuis, 3) R. tenuis subsp. austro-brasiliensis, 4) $R$. enmanuelis, 5) $R$. junciformis and 6) $R$. breviuscula. Note the similarities between $R$. junciformis and $R$. tenuis subsp. austro-brasiliensis, including $R$. enmanuelis, and the differences in relation to $R$. tenuis.

markers were jointly analyzed and compared, they point to new possibilities in respect to the resolution of species/subspecies associated with $R$. tenuis, and reinforce the need for evaluations using different macro and micromorphological features to enhance the taxonomic analysis in this genus.
The literature shows that Rhynchospora junciformis can be differentiated from other species of $R$. sect. Tenues based on the smaller number of spikelets in the tip of culms, morphology of achenes and stylopodium (Barros 1960; Rocha \& Luceño 2002, Strong 2006). Samples collected in Anhanduí exhibited overlap of some morphological features, however this population was differentiated from the other taxa by number of spikelets (1-2), achene shape (rounded to oblate) and stylopodium length $(0.38-0.43 \mathrm{~mm})$. These samples exhibited triangular bilobed shape of stylopodium, which reach one-third of the achene length, being very similar to $R$. junciformis var. monocarpa Kük. described by Barros (1960). However, these were very different from the description of Rocha \& Luceño (2002) and Strong (2006). In this last case the stylopodium appeared to be reduced to a mucro. The karyotype of $R$. junciformis with $2 n=18$ is very similar to that of $R$. tenuis subsp. austro-brasiliensis and $R$. enmanuelis (previously described by Vanzela et al. 2000; Arguelho et al. 2012). The similarities between these three species were also revealed after analysis with ISSR markers, suggesting that $R$. junciformis is relatively well-defined in terms of morphology and seems to be closer to $R$. tenuis subsp. austro-brasiliensis and $R$. enmanuelis than to $R$. tenuis.

Rhynchospora enmanuelis is morphologically very similar to $R$. tenuis subsp. austro-brasiliensis. Rocha \& Luceño (2002) used measurements of leaves, length of the culms, spikelets and stylopodium, number of axillary corymbs (2-3) and, especially, the presence of two stamens, to describe $R$. enmanuelis as a new species. Except for the occurrence of two stamens, all other characteristics were previously described for $R$. tenuis subsp. austro-brasiliensis (Koyama 1972; Strong 2006). Our results showed both $R$. enmanuelis and $R$. tenuis subsp. austro-brasiliensis presenting three stamens, as well as other species of the Rhynchospora tenuis complex (Strong 2006). It is important to point out that the samples of $R$. enmanuelis studied here were collected in the exact same localities of the type specimen, which were studied by Rocha \& Luceño (2002), and that samples of $R$. tenuis subsp. austro-brasiliensis were obtained in the common occurrence area described by Koyama (1972). Another important difference observed here is the presence of short staminodes in several spikelets in both $R$. enmanuelis and $R$. tenuis subsp. austro-brasiliensis. These structures 


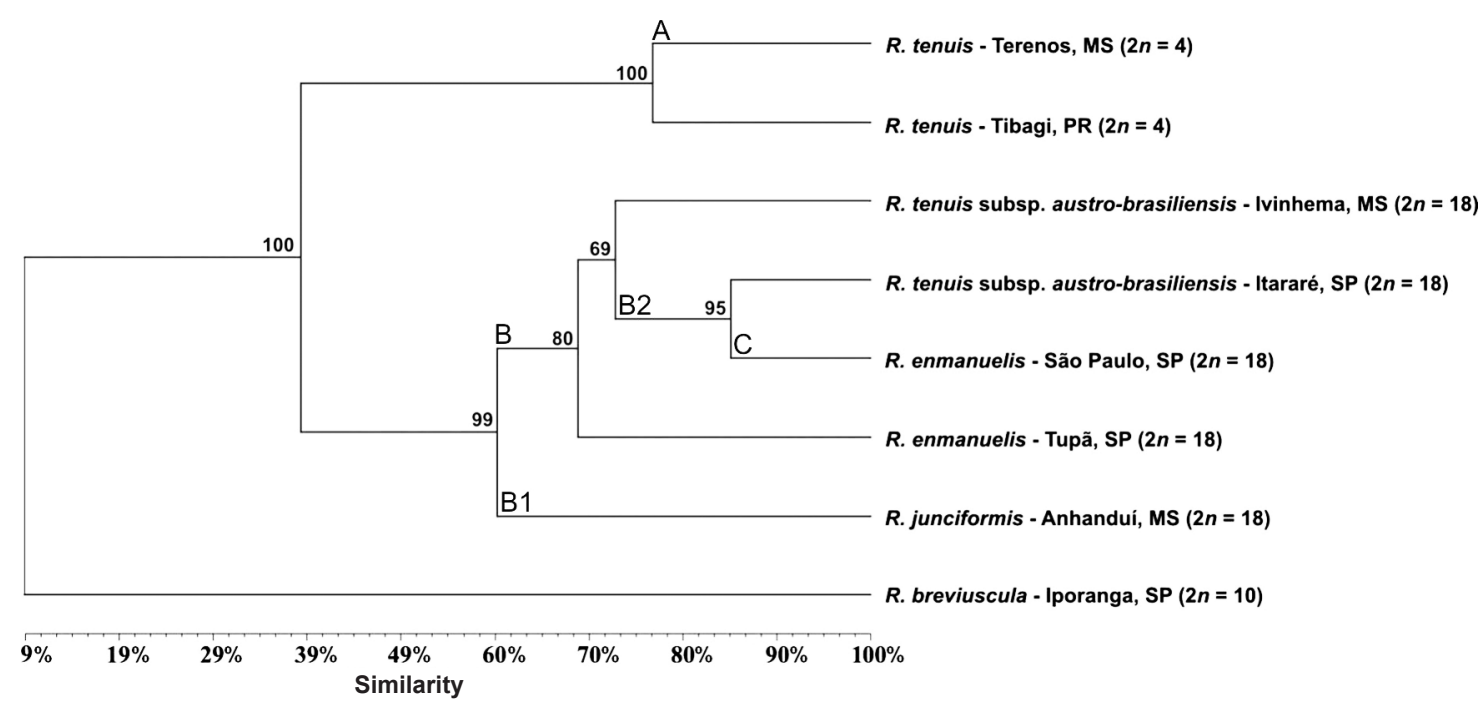

Figure 4 - Phenogram of Rhynchospora tenuis complex. The botton bar refers to Nei \& Li (1979) genetic similarity. All populations were analyzed. Observe that $R$. tenuis subsp. austro-brasiliensis and $R$. enmanuelis are grouped together, closer to $R$. junciformis than $R$. tenuis. Numbers refer to bootstrap values.

had not been mentioned for species of the $R$. sect. Tenues in the reviews of Barros (1960), Koyama (1972), Rocha \& Luceño (2002) and Strong (2006).

Chromosome analysis revealed that $R$. enmanuelis and $R$. tenuis subsp. austro-brasiliensis possess very similar karyotypes, with $2 n=18$ and the $45 \mathrm{~S}$ rDNA in the same chromosome pairs and position. Similarities were also observed after analysis of ISSR markers. The phenogram grouped these two species always in the same clade. The set of information obtained from morphologic, cytogenetic and molecular analyses strongly suggest a deep relationship between these two taxonomic entities.

Koyama (1972) used some features such as anther size, length and shape (curved when mature) of spikelets, and the distance between the corymbs in the culms to define $R$. tenuis subsp. austro-brasiliensis as a subspecies of $R$. tenuis. Our morphologic analysis also showed overlap of several values and characters between $R$. tenuis and $R$. tenuis subsp. austro-brasiliensis, except for subtle differences in the shape and size of achenes. Despite morphological features do not give support to consider $R$. tenuis subsp. austro-brasiliensis as a new species, the information obtained from ISSR markers and karyotypes revealed that there are strong genetic differences between these two entities. The ISSR analysis separated $R$. tenuis from $R$. tenuis subsp. austro-brasiliensis, which exhibited a similarity of only $39 \%$. Interestingly, $R$. tenuis subsp. austro-brasiliensis and $R$. junciformis, both with $2 n=18$, showed $60 \%$ genetic similarity, suggesting that these two species are distant from $R$. tenuis with $2 n=$ 4. It is important to mention that intermediate chromosome numbers between $R$. tenuis and $R$. tenuis subsp. austro-brasiliensis, even in sympatric conditions, were not reported until date.

The occurrence of $7^{\mathrm{II}}+1^{\mathrm{IV}}$ in some samples of $R$. tenuis subsp. austro-brasiliensis indicate a possible polyploid origin for $2 n=18$, associated with dysploidy events. This explanation seems reasonable if we consider the basic number $x=5$ of Cyperaceae (Löve et al. 1957) and the existence of karyotypes with $2 n=10$ in other species of the $R$. sect. Tenues, namely $R$. nanuzae Luceño and Rocha, $R$. riparia and $R$. emaciata (Vanzela et al. 2000). The association of numeric and structural changes in the karyotype differentiation of Cyperaceae were well illustrated in studies within Rhynchospora (Vanzela et al. 1996; Luceño et al. 1998; Vanzela et al. 2000; Arguelho et al. 2012) and Eleocharis (Da Silva et al. 2008a, b, 2010).

The combined use of morphologic, cytogenetic and molecular techniques produced sufficient information to point out new paths toward the resolution of taxonomic problems in the $R$. sect. Tenues. Although we know the necessity of a broader 
analysis, including a larger number of populations and important species such as Rhynchospora nanuzae, $R$. riparia and $R$. emaciata in order to improve the taxonomic resolution in this group, our results have been effective to show the high similarity between $R$. enmanuelis and $R$. tenuis subsp. austrobrasiliensis in relation to other species of the sect. Tenues. The results reinforce also the need of a new taxonomic revision of the Rhynchospora sect. Tenues, especially in the nomenclatural status of $R$. tenuis subsp. austro-brasiliensis and R. enmanuelis.

\section{Acknowledgments}

The authors thank Dr. A. Leyva helped with English editing of the manuscript. Financial support: Fundação Araucária, CNPq and CAPES

\section{References}

Alves, M.V.; Araújo, A.C.; Prata, A.P.; Vitta, F.; Hefler, S.; Trevisan, R.; Bragança, A.S.; Martins, G.S. \& Thomas, W. 2009. Diversity of Cyperaceae in Brazil. Rodriguésia 60: 771-782.

Argelho E.G.; Michelan V.S.; Nogueira F.M.; Da Silva C.R.M.; Rodriguez C.; Trevisan R. \& Vanzela A.L.L. 2012. New chromosome counts in Brazilian species of Rhynchospora (Cyperaceae). Caryologia 65: 140-146.

Barros, M. 1960. Las Cyperaceas del Estado de Santa Catalina. Sellowia 12: 321-369.

Da Silva, C.R.M.; González-Elizondo, M.S. \& Vanzela, A.L.L. 2008a. Chromosome reduction in Eleocharis maculosa (Cyperaceae). Cytogenetic and Genome Research 122: 175-180.

Da Silva, C.R.M.; González-Elizondo, M.S.; Rego, L.N.A.A.; Torezan, J.M.D. \& Vanzela, A.L.L. 2008b. Cytogenetical and cytotaxonomical analysis of some Brazilian species of Eleocharis (Cyperaceae). Australian Journal of Botany 56: 82-90.

Da Silva, C.R.M.; Trevisan, R.; González-Elizondo, M.S.; Ferreira, J.M. \& Vanzela, A.L.L. 2010. Karyotypic diversification and its contribution to the taxonomy of Eleocharis (Cyperaceae) from Brazil. Australian Journal of Botany 58: 49-60.

Doyle, J.J. \& Doyle, J.L. 1990. Isolation of plant DNA from fresh tissue. Focus 12: 13-15.

Gerlach, W.L. \& Bedbrook, J.R. 1979. Cloning and characterization of ribosomal RNA genes from wheat and barley. Nucleic Acids Research 7: 1869-1885.

Koyama, T. 1972. Cyperaceae-Rhynchosporeae and Cladieae. In: Botany of the Guayana Highland. Part
IX. Memoirs of the New York Botanical Garden 23: 23-89.

Kükenthal, G. 1951. Vorarbeiten zu einer Monographie der Rhynchosporoideae. Rhynchospora. Botanische Jahrbücher für Systematik 75: 273-314.

Löve, A.; Löve, D. \& Raymond, M. 1957. Cytotaxonomic of Carex section Cappilares. Canadian Journal of Botany 35: 715-761.

Luceño, M.; Vanzela, A.L.L. \& Guerra, M. 1998. Cytotaxonomic studies in Brazilian Rhynchospora (Cyperaceae), a genus exhibiting holocentric chromosomes. Canadian Journal of Botany 76: 440-449.

Nei, M. \& Li, W.H. 1979. Mathematical model for studying genetic variation in terms of restriction endonucleases. Proceedings of the National Academy of Sciences of the United States of America 76: 5269-5273.

Ohkawa, T.; Yokota, M. \& Hoshino, T. 2000. Aneuploidal population differentiation in Carex sociata Boott (Cyperaceae) of the Ryukyu Islands, Japan. Botanical Journal of the Linnean Society 132: 337-358.

Rocha, E.A. \& Luceño, M. 2002. Estudo taxonômico de Rhynchospora Vahl seção Tenues (Cyperaceae) no Brasil. Hoehnea 29: 189-214.

Strong, M.T. 2006. Taxonomy and Distribution of Rhynchospora (Cyperaceae) in the Guianas, South America. Contributions from the United States National Herbarium 53: 1-225.

Thomas, W.W. 1994. Rhynchospora. In: Davidse, G.; Souza, M.J. \& Chater, A.O. (eds.). Flora Mesoamericana. Vol. 6. Pp. 404-422.

Thomas, W.W.; Araújo, A.C. \& Alves, M.V. 2009. A preliminary molecular phylogeny of the Rhynchosporeae (Cyperaceae). Botanical Review 75: 22-29.

Vanzela, A.L.L.; Guerra, M. \& Luceño, M. 1996. Rhynchospora tenuis Link (Cyperaceae), a species with the lowest number of holocentric chromosomes. Cytobios 88: 219-228.

Vanzela, A.L.L.; Luceño, M. \& Guerra, M. 2000. Karyotype evolution and cytotaxonomy in Brazilian species of Rhynchospora Vahl (Cyperaceae). Botanical Journal of the Linnean Society 134: 557-566.

Vanzela, A.L.L. \& Colaço, W. 2002. Mitotic and meiotic behavior of gamma irradiated holocentric chromosomes of Rhynchospora pubera (Cyperaceae). Acta Scientiarum 24: 611-614.

Zietkiewicz, E.; Rafalski, A. \& Labuda, D. 1994. Genome fingerprinting by simple sequence repeat (SSR)-anchored polymerase chain reaction amplification. Genomics 20: 176-183. 